\title{
СУЧАСНИЙ СТАН ДОСЛІДЖЕНЬ ІДЕОЛОГІЇ МАХНОВСЬКОГО РУХУ В РОСІЙСЬКОЇ ІСТОРІОГРАФІЇ
}

Анотація: У статті окреслено три основні конщепиї російської історіографії махновського руху: 1) дослідження махновського повстанства крізь призму селянської війни в Росії 1917-1921 рр. без акщентуащії на ідеологічних вподобаннях бунтарів; 2) студії махновщини у контексті дослідження російського анархізму; 3) публікаиії, автори яких заперечують анархічний характер махновського руху, за винятком частини його керівництва.

Особливістю сучасної російської історіографії є зміщення зацікавлень дослідників з макроісторичних питань історії громадянської війни на вивчення ідеологічних засад махновського руху, мікроісторичне бойове та трудове повсякдення махновиів і соиіально-психологічні характеристики Нестора Махна. Водночас у Росії спостерігається недооиінка наукового доробку українських дослідників махновського повстання, зокрема, його ідеологічного забарвлення.

Ключові слова: сучасна російська історіографія, тематичні напрями, методологія, махновський рух, селянське повстання, анархізм

Постановка проблеми. Розпад Радянського Союзу, з його системою засекречених архівів, ідеологічної цензури та компартійного диктату, дав потужний імпульс історичним дослідженням на пострадянському просторі, побудованих на оновленій джерельній і методологічній базі. Це стосується і Російської Федерації, де відбувається відкриття «білих плям» та інтенсивне переосмислення багатьох явищ різних періодів радянської історії, у тому числі й періоду революції та громадянської війни.

До таких актуальних тем, які постійно привертають увагу російських гуманітаріїв, належить історія анархізму та махновського руху, котрий був найбільш реальною спробою анархістів втілити омріяний соціальний ідеал у революційній практиці. Як зазначав I. Назаров, у Російській Федерації з кінця 1980-х рр. спостерігався ріст суспільного та наукового інтересу до альтернативних теорій суспільної перебудови, у тому числі до анархізму і селянського руху під проводом Н. Махна, як однієї з найбільш реальних спроб анархістів втілити свій соціальний ідеал на практиці․ Так само й В. Савченко спостеріг «прорив» у дослідженні анархістського руху 1903-1920 рр. російськими науковцями, які спро-

\footnotetext{
* Гудзь Віктор Васильович - доктор історичних наук, доцент кафедри історії та археології, Мелітопольський державний педагогічний університет імені Б. Хмельницького (м. Мелітополь, Запорізька область, Україна); ORCID: https://orcid.org/0000-0001-5756-1683; e-mail: goodz-klio@ukr.net Ковальов Максим Володимирович - аспірант кафедри історії та археології, Мелітопольський державний педагогічний університет імені Б. Хмельницького (м. Мелітополь, Запорізька область, Україна);

ORCID: https://orcid.org/0000-0003-0660-4035; e-mail: maxim-k-v@ukr.net

${ }^{1}$ Назаров И.Ю. Идеология и политическая практика махновского движения: автореф. дисс... канд. ист. наук: 07.00.02. Москва, 2006. 32 с.
} 
стували радянські кліше про рух «бандитів і босяків»².

Водночас, з початком «гарячої» фази гібридної війни Росії з Україною, у російському науковому просторі побільшало спроб фальсифікації історії України та дискредитації iї державницьких сил. Наприклад, на одному з російських пропагандистських інтернетресурсів публіцист С. Павленко проводить паралель між махновцями-анархістами й учасниками Революції Гідності та стверджує, що у незалежній Україні створено культ бандита-Махна: «Однак по-справжньому цього бандита-перебіжчика стали використовувати після “помаранчевої революції. ....Махна внесли до пантеону борців за незалежність України від “москалів"»".

На тлі таких публікацій, постає наукова проблема історіографічного опрацювання значного масиву російської літератури з історії селянських повстань та анархізму 19171921 років, у тому числі питань ідеології махновського руху, а також проблема захисту інформаційного простору України від ідеологічних диверсій адептів «руского міра» у царині української історичної пам'яті.

Аналіз останніх досліджень і публікацій. У роки незалежності здійснено декілька публікацій про стан та особливості дослідження тих чи інших проблем селянського руху, або махновщини й анархізму в Україні загалом. У деяких з них, крім українських, аналізувалися і російські розробки з історії махновського руху та діяльності ватажка повстанців. Йдеться, насамперед, про історіографічні роботи О. Бабічевої ${ }^{4}$, О. Зеленяка ${ }^{5}$, Т. Мармазової автори яких побіжно чи фрагментарно розглядали і деякі російські дослідження.

Своєрідний підсумок цих наукових розробок становить перше, і поки що єдине, кваліфікаційне дослідження з історіографії махновського руху Т. Мармазової․ Дослідниця класифікувала історіографічні джерела та встановила внесок окремих істориків, у тому числі й російських, у дослідження окремих аспектів махновського руху. Огляди російських публікацій з тематики махновщини й анархізму в Україні міститься й у низці історичних досліджень, як-от: В. Савченка, В. Чопа, В. Кривенького, І. Назарова, О. Шубіна й ін. ${ }^{8}$

\footnotetext{
${ }^{2}$ Савченко В.А. Анархістський рух в Україні в 1903-1929 рр.: організаційні форми, комунікації і механізми функціонування: дис... д-ра іст. наук: 07.00.01. Київ, 2017. С. 59.

${ }_{3}^{3}$ Павленко Сергей. Махно как карнавальная фигура украинской идеологии // Фонд стратегической культуры. URL: https://www.fondsk.ru/news/2019/04/11/mahno-kak-karnavalnajafigura-ukrainskoj-ideologii-47972.html

${ }^{4}$ Бабічева О.С. Історіографія дослідження анархістського руху в Україні в добу національно-демократичної револющії 1917-1921 рр. // Грані. 2007. № 6. С. 12-17.

${ }_{5}^{5}$ Зеленяк О.М. Огляд радянської та зарубіжної історіографії повстанського руху під проводом Нестора Махна у другій половині 50-х - початку 90-х років ХХ ст. // Наукові праці історичного факультету ЗНУ. 2015. Вип. 44, Т. 2. С. $190-193$.

${ }^{6}$ Мармазова Т.І. Співвідношення соціальних і національних мотивів повстанського руху під керівництвом Н.І. Махна: історіографічний аналіз // Вісник Київського інституту «Слов'янський університет». 2002. № 12. C. 166-173.

${ }^{7}$ Мармазова T.I. Історіографія повстанського руху в Україні під проводом Н.І. Махна (1918-1921 рр.): дис... канд. іст. наук: 07.00.06. Донецьк, 2003. 217 с.

${ }^{8}$ Шубин А.В. Анархистский социальный опыт: Украина и Испания 1917-1939 гг.: автореф... д-ра ист. наук: 07.00.03. Москва, 1999; Чоп В.М. Махновський рух в Україні 1918-1921 роки: проблеми ідеології, суспільного та військового устрою: автореф... канд. іст. наук: 07.00.01. Запоріжжя, 2002. 289 с.; Назаров И.Ю. Идеология и политическая практика махновского движения: дис... канд. ист. наук: 07.00.02. Москва, 2006. 191 с.; Кондрашин В.В. Отечественная и зарубежная историография крестьянского повстанческого движения в годы гражданской войны // Крестьянский фронт 1918-1922 гг.: сб. статей и материалов. Москва: АИРО-XXI, 2013. С. 24-
} 
Проте, як це зазвичай буває, історіографічне осмислення теми дещо відстає у часі за кількістю та якістю від емпіричних напрацювань. Зокрема, спеціальні публікації про стан і тенденції російської історіографії махновського руху в бібліографічних покажчиках нам не зустрічалися.

Формулювання цілей статті. Відтак, мета нашої роботи - історіографічне дослідження основних праць із сучасного російського «махнознавства» задля характеристики його загального стану і оцінок дослідниками ідеологічного забарвлення махновщини.

Виклад основного матеріалу дослідження. Упродовж століття дослідження теми вже детально вивчено перебіг бойових дій, які вела Революційна повстанська армія України (РПАУ) з різними супротивниками, встановлено хронологічну послідовність військових кампаній і політичних союзів повстанців під проводом Н. Махна, висвітлено біографію повстанського «батька» тощо. Зважаючи на зміст досліджень російських науковців і публіцистів після розпаду СРСР, розглянемо, насамперед, особливості висвітлення ними деяких теоретичних питань історії махновщини. До кола цих проблемних питань, зокрема, належать характер махновського повстання; ступінь впливу на Махна та махновців анархістської ідеології; розробка «батьком» і його соратниками анархістської теорії; ступінь української самоідентифікації Н. Махна та його армії; соціально-економічні мотиви махновського руху тощо. У заочній дискусії щодо впливу на махновців анархістського чинника і міри відповідності анархо-комуністичних настроїв українській селянській ментальності резонні аргументи висловлено у публікаціях В. Коміна, С. Сєманова, О. Шубіна й ін. ${ }^{9}$ Деякі дослідники вийшли на тему специфіки українського анархізму, який полягав у його персоніфікованому вияві (В. Єрмаков ${ }^{10}$, О. Шубін $\left.{ }^{11}\right)$.

Так, одна з останніх робіт О. Шубіна ${ }^{12}$ містить аналіз перипетій практичної боротьби повстанців за свої ідеали з позицій анархістської ідеології, що зумовило деяке перебільшення автором міри впливу анархістів на махновський рух. О. Шубін простежив соціальні корені махновщини, передумови та причини зародження збройного селянського опору, ідейно-політичні трансформації та військові спілки повстанців тощо. Зрештою, дослідник залишився вірним обраній парадигмі, дійшовши висновку, що махновський рух на всіх етапах боротьби був спрямований на досягнення анархічного ідеалу ${ }^{13}$. Особливістю праць О. Шубіна є розгляд, поряд з власне анархо-махновщиною 1918-1921 рр., дія-

47; Савченко В.А. Діяльність анархістських організацій в Україні у 1903-1929 рр: історичний аспект та політична практика: монографія. Київ: Поліграф. д-ця Ін-ту історії України НАН України, 2017. 444 с.; Кривенький В.В. Анархистское движение в России в первой четверти XX в.: теория, организация, практика. Москва: Политическая энциклопедия, 2018. 430 с.

${ }^{9}$ Комин В.В. Нестор Махно: мифы и реальность. Калинин: Московский рабочий, 1990. 79, [2] с.; Семанов С.Н. Под черным знаменем, или Жизнь и смерть Нестора Махно. Москва: Тов-во «Возрождение», 1990.76 с.; Ceманов С.Н. Махно. Подлинная история. Москва: ЗАО Компания «АСТ-ПРЕСС», 2001. 318 с.; Шубин А.В. Махно и махновское движение. Москва: «Пик», 1998. 176с.; Shubin Alexander. Die Machno-Bewegung und der Anarchismus. Anarchismus. und Russische Revolution. Berlin, 2017. S. 17-22.

${ }^{10}$ Ермаков В.Д. Анархисты на фронтах Гражданской войны 1917-1922 годов. Санкт-Петербург: СПбГИК, 2018. 272 c.

${ }^{11}$ Шубин А.В. Махно и его время: О Великой революции и Гражданской войне 1917-1922 гг. в России и на Украине. Москва: ЛИБРОКОМ, 2013. 320 с.

${ }^{12}$ Ibidem.

${ }^{13}$ Ibid. C. 307-308. 
льності російського анархізму в еміграції, у тому числі маловідоме повсякдення Н. Махна в Парижі. Предметно досліджено створення у 1927 р. Нестором Махном і П. Аршиновим «Платформи» - програми подальшої боротьби анархістів за омріяний соціальний ідеал ${ }^{14}$. О. Шубін, критикуючи програмні ідеї «Платформи», схвалив «класичний» анархістський напрямок, який, на його думку, був значною мірою реалізований у соціальноекономічному устрої махновських та іспанських комун ${ }^{15}$. На думку О. Шубіна, постреволюційна махновщина, представлена «Платформою», була вираженням анархокомуністичного радикалізму, наближенням до державності від чого, зрештою, закономірно відмовилися авторитетні зарубіжні та російські анархісти, зокрема А. Беркман, М. Корн, В. Волін, Г. Максімов та ін.

О. Шубін, намагаючись уникнути відвертої апологетики анархізму, у своїх працях опирається на документи, об’єктивно висвітлює стан анархічного руху в революційну добу та визнає організаційні помилки його керівництва. Водночас історик показав важливу роль, яку відіграли махновці в історії громадянської війни, претендуючи на третю силу у протистоянні «білої» та «червоної» Росії, а також спростував радянські міфи про «куркульський бандитизм» махновців, про безглуздість їх протистояння більшовикам і про відсутність у них будь-якої реалістичної програми. Проте О. Шубін замовчав питання про соціальну деградацію і жорстокість решток махновців, переслідуваних більшовицькими військами у 1921 р., що давало підстави деяким науковцям звинуватити повстанців у бандитизмі. Зокрема, В. Комін наприкінці «перебудови» (1990 р.) ще поділяв більшовицькі оцінки махновщини як куркульського політичного бандитизму ${ }^{16}$

Інший фаховий історик, В. Єрмаков, у 1991 р. все ще вважав, що махновщина мала яскраво виражений куркульсько-бандитський характер, чому не останньою мірою сприяли дві основні риси в ідеології українського селянства: анархо-індивідуалістичний світогляд і прагнення самостійності ${ }^{17}$. Автор наголосив, що особливі соціальні умови, які склалися на Півдні України (родючі землі, великі наділи, заможне селянство, хутори та колонії) зробили можливим появу махновщини, як своєрідного селянського різновиду російського анархізму ${ }^{18}$.

У своїй новій монографії В. Єрмаков відійшов від радянських стереотипів дійшов висновку, що партизансько-повстанський рух під орудою Н. Махна був найпотужнішим селянським рухом, знаходився під найбільшим, у порівнянні з іншими повстанськими рухами, впливом анархістів й очолювався переконаним анархістом ${ }^{19}$. Проте, за Єрмаковим, у критичні моменти історії, коли стояло питання про збереження РПАУ та «Махновії», Махно все ж відсував анархізм на другий план: «Коли ж на перший план випливали питання самого існування махновщини як руху, тобто військового характеру, батько йшов на конфлікт з ідейними анархістами, в тому числі і з керівниками Конфедерації

\footnotetext{
${ }^{14}$ Ibid. C. 302-312.

${ }^{15}$ Шубин А.В. Анархистский социальный опыт...

${ }^{16}$ Комин В.В. Нестор Махно...

${ }^{17}$ Ермаков В.Д. Махновщина: некоторые социально-бытовые аспекты повстанческого движения крестьян Украины // Социологические исследования. 1991. № 3. С. 76-86.

${ }^{18}$ Ibid. C. $84-85$.

${ }^{19}$ Ермаков В.Д. Анархисты на фронтах Гражданской войны 1917-1922 годов. Санкт-Петербург: СПбГИК, 2018. C. 132.
} 
“Набат"»"20. На підтвердження своєї думки, В. Єрмаков навів заяву штабу РПАУ, в якій, 3 одного боку, ототожнювалися махновщина й анархізм, а з іншого - зізнання Н. Махна про те, що він радо залучав анархістів до повстанських лав, але махновці цінували лише тих 3 них, хто, крім агітації словом, міг стати пліч-опліч у критичних військових ситуаціях ${ }^{21}$.

Деякі протиріччя у визначенні ступеня анархізованості махновців можна спостерегти у вступній статті С. Волка до видання спогадів Н. Махна ${ }^{22}$. Наприклад, несприйняття махновцями центральної влади і надісланих нею червоних комісарів чи білих емісарів, історик пояснив своєрідним стихійним анархізмом українського селянства, який полягав у їх прагненні безвладдя й економічної свободи на засадах рівноправного комуністичного укладу життя. Відтак, повстанці Батька Махна захищали власні інтереси справедливого самоврядування, які істотним чином збігалися з постулатами теорії анархо-комунізму 23 . Проте надалі автор, не вдаючись до аргументації на фактах, дійшов хибного висновку, що українському селянству були близькими російські анархічні ідеї. Як відомо, традиційна російська община і хутірське господарювання із нахилом до індивідуальної свободи, поширене на Гуляйпіллі - явища не автентичні, так само як і ментальність українських і російських селян.

Відомий знавець історії російського анархізму В. Кривенький у своїй добротно документованій праці ${ }^{24}$ провів класифікацію анархістських груп і центрів, та, зокрема, висвітив деякі маловідомі сюжети зв'язків махновців із бойовиками Всеросійської організації анархістів підпілля (ВОАП). Історик зазначив, що московські «анархісти підпілля» влітку 1919 р. отримали грошову допомогу від представників махновського штабу. Зважаючи на випуск москвичами у серпні 1919 р. 10 тис. примірників листівки «Правда про махновщину» та їх заяву, що вересневий теракт у Леонтьєвському провулку був відповіддю на розстріл більшовиками махновських командирів у Харкові, очевидно, така взаємодопомога мала місце. Описаний автором епізод про арешт чекістами і показання членкині конфедерації анархістських організацій України «Набат» С. Каплун, яка їхала на зв'язок 3 анархістами у Брянську, також засвідчує певну координацію дій «махновських» анархістів 3 російськими групами ${ }^{25}$. Та більше, В. Кривенький підтримав версію сучасного українського анархіста В. Азарова, який «...вельми обгрунтовано вважає появу ВОАП майже на $100 \%$ справою рук махновської контррозвідки» ${ }^{26}$. Свої дані про махновський слід навів і Д. Рубльов: «3 Харкова в центральну Росію виїхала група з 25 бойовиків, організована махновськими контррозвідниками. В їх планах було організувати в Харкові замах на Троцького і підрив будівлі ВУЧК. Потім передбачався замах на Леніна в Москві ${ }^{27}$.

Проте, попри потужну джерельну базу монографії, оперту на майже два десятки архівосховищ 4-х держав, у тому числі й України, В. Кривенький лишив поза увагою дія-

\footnotetext{
${ }^{20}$ Ермаков В.Д. Анархисты на фронтах... С. 132.

${ }^{21}$ Ibid. C. 129-131.

${ }^{22}$ Волк С.С. Нестор Махно в дни войны и мира // Махно Нестор. Воспоминания. Москва: Республика,1992. C. 3-26.

${ }^{23}$ Волк С.С. Нестор Махно... С. 10.

${ }^{24}$ Кривенький В. В. Анархистское движение...

${ }^{25}$ Ibid. C. 309-311, 313, 315.

${ }^{26}$ Ibid. C. 310.

${ }^{27}$ Рублев Дм. Российский анархизм в XX веке. Москва: Родина, 2020. 900 c. URL: http://loveread.ec/read_book.php?id=92109\&p=123
} 
льність «набатівців» у керівництві РПАУ, питання впливу анархістів на махновців та їх «батька», а також репресії проти махновців та анархістів України 1921-1925 рр. Так, левова частка підрозділу 4.2. із синкретичною назвою “Чорна гвардія”, анархо-бандитизм, повстанство, махновщина» присвячена спробі Я. Тряпіцина втілити на практиці ідеї анархізму та максималізму, втіливши у проекті «Миколаївська-на-Амурі комуна» (1920 р), а махновцям відведено лише кілька абзаців у контексті їх співробітництва з «анархістами підпілля». Тому викликає подив наступна фраза В. Кривенького: «У східній частині країни, як відомо, протягом більш довгого періоду часу (з невеликими перервами) існував Гуляй-Пільський варіант соціально-громадської перебудови під керівництвом Н.І. Махна (цей сюжет буде розглянутий трохи пізніше)» ${ }^{28} .3$ цитованого тексту, випливає, що автор, по-перше, мав на увазі вираз «у східній частині України», а не «країни», а по-друге забув про обіцяний сюжет «ГуляйПільського варіанту соціально-громадської перебудови». Не відповідають загальному рівню монографії і куці (0,5 сторінки) висновки, що, як на нас, засвідчує певний перекіс автора у бік фактології, за браком кінцевих синтезних узагальнень.

Дещо більше місця історія махновського руху займає у розділі «Третя революція» і «вільні безвладні ради» (1919-1921 рр.) новітньої монографії російського фахівця з історії анархізму Д. Рубльова ${ }^{29}$. Історик простежив процес інтеграції анархістів Конфедерації анархістів України (КАУ) «Набат» 3 гуляйпільською групою анархістів у першій половині 1919 р. За Рубльовим, В. Білаш встановив контакт з «набатівцями» вже в січні і спілка Гуляйпільської групи анархістів «Набат» та виконкому Військово-революційної ради (ВРР) Гуляйпільського району була закріплена їх спільним зверненням. У лютому І. Тарасюк заснував у махновській столиці групу, що входила до складу конфедерації «Набат» і видавала газету «Гуляйпільський набат», а в травні «набатівці» об'єдналися з Гуляйпільської групою анархістів-комуністів. Відтак, як вважає Д. Рубльов: «3 травня 1919 г. «Набат» встановив зв'язок 3 махновських рухом» ${ }^{30}$. Проте, як виглядає, у травні сталося не встановлення зв'язку «набатівців» і махновців, а їх об’єднання шляхом залучення провідних анархістів В. Воліна, М. Мрачного, Я. Алого й ін. на керівні посади у вищих політичних структурах РПАУ-ВРР, Культпросвітвідділ, до редагування газети «Шлях до свободи» тощо.

Д. Рубльов спробував також проаналізувати програмні гасла у документах махновців, які нібито змінилися з осені 1919 р., після розриву з більшовиками, «набуваючи відкрито анархістського характеру, близького політичній платформі КАУ «Набат». Історик аргументує свою думку тим, що в осінніх листівках йдеться про «безвладні Ради робітничих і селян», повторюється гасло «третьої революції». 3 цього приводу, думається, варто було б наголосити, що махновці допускали лише тактичні зміни, не відступаючи від власних стратегічних вимог, які співпадали з анархо-комуністичними та реалізувалися у політичній практиці трьох регіональних з'їздів і «Південної безвладної трудової федерації». Адже із цитованих матеріалів пересвідчуємося, що, попри спільну для повстанців країни негацію до «військового комунізму» і «червоного» та «білого» терору, махновці та «набатівці» послідовно поділяли спільні гасла: «Хай живе вільна безвладними анархічна комуна»

\footnotetext{
${ }^{28}$ Кривенький В.В. Анархистское движение... С. 324.

${ }^{29}$ Рублев Дм. Российский анархизм...

${ }^{30}$ Ibid. URL: http://loveread.ec/read_book.php?id=92109\&p=120

${ }^{31}$ Ibidem.
} 
(січень, заява «Набат» і виконкому ВРР); «вільно обрані робітничо-селянські Ради», «соціалізація землі» (лютий, резолюція 2-го Гуляйпільського районного з'їзду); «вільне виборне начало (в ради)», «соціалізація землі і підприємств» (квітень, резолюція 3-го з'їзду повітів Катеринославщини); «безвладна федерація економічних організацій» (серпень, листівки РПАУ); «вільні органи економічного самоврядування» (жовтень 1920 р., 4-й пункт угоди між командуванням РПАУ та більшовицького Південного фронту).

Викликають питання і деякі інші судження й оцінки Д. Рубльова, як-от про те, що режим «Південної безвладної трудової федерації», являв собою «дещо демократизований (внаслідок ідеологічного впливу анархістів і необхідності отримувати підтримку місцевого населення) варіант військової диктатури» ${ }^{32}$, який впроваджували штаб РПАУ і коменданти. Дійсно, диктатура штабу РПАУ і комендантів, як і вимагав воєнний час, здійснювалася у захоплених махновцями містах, але вважаємо, що некоректно відносити такий режим і до гуляйпільської «Федерації», де для вирішення важливих питань скликалися загальні З’їзди, а виконавча влада належала виборній Військовій Революційній Раді. Адже, як визнав автор, попри значний вплив Н. Махна і його штабу, далеко не всі рішення про політичний курс руху залежали винятково від волі «Батька», залежного і від близького анархістського та військового оточення і від селянських настроїв. Як на нас, зважаючи на махновську практику самоврядування, навряд чи коректним є тлумачення, вслід за М. Мрачним, махновського руху як прояву «втечі від свободи» під руку сильного вождя: «Махно сприймався так само як і Ленін, - в якості одного з політичних лідерів, яким селяни делегували владні повноваження і бачили захисника, здатного навести порядок...»³. Загалом, хоча Д. Рубльов поділяє більшість оцінок махновщини у працях П. Аршинова й О. Шубіна, поставлені ним дискусійні питання «дають хліб» для подальшого наукового осмислення.

Іншу групу російських істориків об'єднує заперечення тверджень про наявність анархістського соціального ідеалу в українського селянства, яке складало основу махновського руху. П. Альошкін, В. Голованов, В. Теліцинта й інші російські фахівці з історії махновщини, спростовують судження про ідеологічний вплив анархістів на широкі махновські маси і доводять тезу про стихійний характер цього селянського руху на Лівобережжі України. Наприклад, на переконання В. Теліцина, махновський рух був радше пошуком власного селянського шляху до рівності та свободи, ніж цілеспрямованою ідейною боротьбою: «Махно - третя сила, яка в бурхливому морі революції і громадянської війни шукала свій шлях ${ }^{34}$.

Про стихійний зміст махновського руху йдеться і в монографії П. Альошкіна та Ю. Васильєва: «Саме Троцький почав роздмухувати міф про анархістську природу махновщини, щоб затулити її народний селянський зміст» ${ }^{35}$. Дійсно, як справедливо зазначили налаштовані проти «випинання анархістської оболонки махновщини» історики, не махновці примкнули до анархістів, котрі за визнанням П. Аршинова, відставали від революційної творчості мас, а група анархістів-комуністів залучилася до руху в якості політпрацівників $^{36}$. П. Альошкін і Ю. Васильєв навели низку аргументів на доказ своєї тези про те,

\footnotetext{
${ }^{32}$ Ibid. URL: http://loveread.ec/read_book.php?id=92109\&p=122

${ }^{33}$ Ibid. URL: http://loveread.ec/read_book.php?id=92109\&p=165

${ }^{34}$ Телищын В.T. Нестор Махно: Историческая хроника. Москва: Олимп; Смоленск: Русич, 1998. С. 442.

${ }^{35}$ Алешкин П.Ф., Васильев Ю.А. Крестьянская война в России в условиях политики военного коммунизма и ес последствий (1918-1922 гг.). Москва: Голос-Пресс, 2010. С. 209.

${ }^{36}$ Ibid. C. 211.
} 
що інтереси селян не суперечили стихійного анархізму, але анархізм у малописьменних масах повстанців не сприймався як політичне вчення. «Хто читав анархістські видання? Неосвічена селянська маса?»» ${ }^{37}$ - риторично запитали автори, перебільшуючи у запалі полеміки неосвіченість повстанців, які слухали численних агітаторів і промовців на вічових сходах, мітингах і власний культпросвіт. Водночас історики навели переконливі факти на підтвердження своєї тези про те, що життєва практика махновського руху зруйнувала анархістські ідеальні теорії як у площині самоврядування й економіки, так і у військовій сфері. Загалом висновки П. Альошкіна щодо застосування анархістської теорії на практиці виглядають занадто категоричними. Так, у своїй докторській дисертації історик стверджував: «Анархістська умоглядна теорія, як ідеологія радикального революційного спрямування, виявилася далекою від справжніх інтересів трудящих» ${ }^{38}$

Як на нас, заява науковця занадто категорична і містить недооцінку реальної співпраці махновців і анархістів у реалізації принципів побудови гуляйпільської Махновії і повстанської армії. Справедливо заперечуючи типологію махновського руху в якості анархістського, П. Альошкін впадає в іншу крайність, коли не виносить це явище за рамки типології загальноросійського селянського руху, з притаманним останньому етатизмом, вірнопідданством, асоціацією легітимності верховної влади з ідеєю про сакральність влади. Думається, самоврядування махновців з його сходами та з'їздами не вписується в історично правильну формулу щодо російського селянства: «Селянство ніколи не асоціювало себе в якості суб’єкта реальної політики, добровільно віддаючи цю функцію державі» ${ }^{39}$.

В. Голованов також заперечив істотний вплив теоретиків анархізму на махновців і наполіг на стихійному характері цього селянського руху, який, на його думку, надихався романтикою і традицією козацької доби, у тому числі й у випадку обрання отамана«батька ${ }^{40}$. Дослідник переконаний: «У порівнянні з більшовицькою «диктатурою пролетаріату» махновщина - це романтичний марш назад, у минуле, до часів Запорізької Січі, вольності лівобережного козацтва, оселянені нащадки якого знову намагалися здобути собі свободу і братню рівність. Анархізм був лише сучасною формою, в яку втілювалися ці вікові умонастрої» ${ }^{41}$. Відповідно Батько Махно, в уявленні письменника, був ідеалом самовідданого бунтаря, який програв фактично, але переміг історично у боротьбі із закостенілою системою більшовизму. Інша книжка В. Голованова має підзаголовок «художнє дослідження махновського руху» ${ }^{42}$, що свідчить про їі популярний характер, але варта окремого фахового аналізу, бо базується на історичних джерелах. Загалом, праці В. Голованова є одними з кращих зразків поєднання науковості, включно з уведенням в обіг архівних матеріалів, з оригінальним літературним стилем.

Так само зважену позицію щодо оцінки впливу анархізму на махновців зайняли упорядники найбільшого на сьогодні збірника документів з історії махновського руху

\footnotetext{
${ }^{37}$ Ibid. C. 217.

${ }^{38}$ Алешкин П.Ф. Крестьянское протестное движение в России в условиях политики военного коммунизма и ее последствий: 1918-1922 гг.: автореф.... дис. д-ра ист. наук: 07.00.02. Москва, 2012. С. 13.

${ }^{39}$ Алешкин П.Ф. Крестьянское протестное движение в России в условиях политики военного коммунизма и ее последствий: 1918-1922 гг.: дис. д-ра ист. наук: 07.00.02. Москва, 2012.

${ }^{40}$ Голованов В. Нестор Махно. Москва: Молодая гвардия, 2013. 482 [14] с: ил.

${ }^{41}$ Ibid. C. 21.

${ }^{42}$ Голованов В. Тачанки с юга. Художественное исследование махновского движения. Москва: «МАРТ», 1997. $454 \mathrm{c}$.
} 
Т. Шанін, В. Кондрашин і Н. Тархова ${ }^{43}$. Науковці відзначили, що ідеї анархізму перепліталися, насамперед, у площині общинної свідомості селян і їх досвіду господарювання за традиціями сільської громади. «Опубліковані документи, проте, свідчать, що анархісти не чинили вирішального впливу на прийняття рішень у повстанської армії, не командували нею і не керували Батьком Махно» ${ }^{44}$, - наголосили історики. У своїй пізнішій публікації, присвяченій спростуванню міфів про махновщину, В. Кондрашин висловив аналогічну оцінку співвідношення стихійності та ідейності повстанців: «Це був селянський рух, в якому анархісти брали активну участь завдяки тому, що на чолі його виявився анархіст i ідеї анархізму збігалися із селянськими уявленнями про цілі їх боротьби» ${ }^{45}$. Водночас історик навів маловідомі факти, які спростовують радянські інсинуації, також скепсис П. Альошкіна і Ю. Васильєва щодо рівня освіченості і культури Н. Махна і принципів добровільності та виборності у РАПУ.

Загалом питання ролі анархістів у махновському русі та рівня анархізованості повстанського ядра стало одним із постійних об’єктів дослідницького інтересу науковців Росії. Дослідники здебільшого заперечували глибоке проникнення анархістських ідей у малописьменні маси повстанців, але визнавали відданість анархізму не лише представника «Набату» В. Воліна, революціонера П. Аршинова, а й самого Н. Махна та більшості його провідних соратників.

Останнім часом багато «списів» ламається російськими науковцями щодо історіософської проблеми співвідношення соціальних і національних мотивів махновського руху та впливу козацького звичаю на повстанців Н. Махна. Одним із перших у світовій історіографії спеціально дослідив це питання В. Чоп, який відзначив існування двох підходів до вивчення історичного зв'язку між Військом Запорозьким Низовим і РПАУ(м), які спершу склалися у середовищі українських емігрантів. Одні історики розглядали махновських повстанців як нащадків і продовжувачів традицій Запорозької Січі. Інші наполягали на співпадінні спільних ознак в історії означених явищ, або на штучності спроб махновського покозачення ${ }^{46}$. Особисто В. Чоп і його співавтор, І. Лиман, підтримали та розвинули концепцію тяглості запорозьких традицій у махновському середовищі ${ }^{47}$.

Натомість російські науковці, як правило, розвивали ідеї про штучність козацької атрибутики та брак національної свідомості у махновських лавах, але відзначали вплив на махновську верхівку народної стихії Гуляйпільщини й інших питомо українських регіонів. В. Голованов, С. Сєманов, В. Теліцин та інші дослідники відзначали, що зародження та розгортання махновського руху було пов'язано з необхідністю боротьби селянства 3

\footnotetext{
${ }^{43}$ Шанин Т., Кондрашин В., Тархова Н. Введение. Нестор Махно. Крестьянское движение на Украине. 19181921: Документы и материалы / Серия: Крестьянская революция в России. 1902-1922 гг.: Документы и материалы / Под ред. В. Данилова и Т. Шанина. Москва: «Российская политическая энциклопедия» (РОССПЭН), 2006. C. 5-34.

${ }^{44}$ Шанин Т., Кондрашин В., Тархова Н. Введение ... С. 21.

${ }^{45}$ Кондрашин В.В. Повстанческая армия Махно: мифы и реальность «Атаманщина» и «партизанщина» в Гражданской войне: идеология, военное участие, кадры. Сборник статей и материалов. / Под ред. А.В. Посадского. Москва: АИРО-ХХІ, 2015. 856, 20 с. илл.

${ }^{46}$ Чол В.M. Проблема існування Запорозьких козацьких традицій в історії махновського руху // Записки історичного факультету ОНУ імені І.І. Мечникова. 2006. Вип. № 17. С. 196.

${ }^{47}$ Чоп B.M., Лиман I.I. Нащадки запорожців: махновський рух у Північному Приазов'ї (1918-1921 рр.). Мелітополь: Вид. буд. ММД, 2019. 609 с.
} 
антинародною політикою як окупаційних, так і власне українських урядів, зокрема, у період гетьманату П. Скоропадського.

Російські історики спостерегли періодичне посилення націоналістичних настроїв серед селянства України, насамперед на завершальному етапі німецько-австрійської окупації та під час другого походу більшовиків на Україну у 1919 р. Водночас більшість дослідників (В. Єрмаков, І. Назаров, О. Шубін та ін.) документально спростували досить поширені інсинуації щодо махновських погромів єврейського населення. Російськоізраїльський дослідник М. Гончарок, розглядаючи махновський рух крізь призму «єврейського питання», також на фактах заперечив твердження у радянської історіографії та історика I. Чериковера про антисемітський характер руху ${ }^{48}$.

Що стосується січових традицій демократії і свободолюбства, та й самого факту козацького походження багатьох гуляйпільців, то деякі російські дослідники вказують на врахування Н. Махном і його місцевими соратниками такого чинника. Щоправда, вважається, що «Батько» вкладав у поняття козацького феномену не стільки українську національну сутність, скільки формальну соціально-побутову традицію. Проте, на наш погляд, думка В. Коміна про розуміння Н. Махном нереальності створення «Січі XX століття» на засадах вільного самоврядування ${ }^{49}$ потребує додаткової аргументації. Адже Вільна Махновія, про яку промовляли повстанці на кожному мітингу, видавалася анархістським ідеологам руху, та й самому «Батькові», як свідчать його спогади, не просто ідеалом соціального устрою, а й, частково, практикою порядкування Гуляйпільської трудової республіки та порядків у Революційної Повстанської Армії України. Власне те, що суспільнополітична концепція Н. Махна була пов'язана з долею українського народу, свідчать і назва й устрій повстанської армії, і програмні установки руху та побут махновців. Як відомо, російські більшовики, які навесні 1919 р. вже керували Україною, переслідували, насамперед, українських самостійників. Натомість 10 квітня цього року, третій Гуляйпільський з'їзд представників 72 волостей і 4-х військових формувань Катеринославщини, почесним головою якого був обраний Н. Махно, ухвалена резолюція, в якій протест проти військово-комуністичної політики «комуністів-більшовиків» поєднувався із закликом до робітників, селян, повстанців і червоноармійців припинити «будь-яке національне цькування» ${ }^{50}$. Нарешті, влітку 1919 року Н. Махно пішов на тимчасове співробітництво 3 Директорією. Щоправда, на думку російських дослідників, мотиви такого рішення були скоріше військо-тактичними, ніж через національну солідарність.

Власну думку щодо ідеології махновщини висловив С. Сєманов, який, значною мірою, опирався на відомості, отримані з особистих бесід у Джамбулі із Галиною Кузьменко, вдовою Н. Махна. Повстанці Н. Махна у публікаціях С. Сєманова постають, в основному, як послідовні борці за щастя трудового люду, які, проте, для досягнення цієї мети не зупиняються перед розстрілами та «конфіскаціями», впадають у розгул та анархію. У своїй праці «Під чорним прапором...» автор представляв селянську війну під орудою Н. Махна

\footnotetext{
${ }^{48}$ Гончарок М. Век воли. Русский анархизм и евреи (XIX-XX вв.). Иерусалим: «Мишмерет шалом», 1996. 123 с.

${ }^{49}$ Комин В.В. Нестор Махно... С. 49.

${ }^{50}$ Резолюиия 3-го районного съезда представителей волостей и уездов Екатеринославской губернии, повстанческих фронтовых частей в поддержку действий Махно. 10 апреля 1919 г. // Нестор Махно. Крестьянское движение на Украине... С. 111-112.
} 
як своєрідну народну стихію. Водночас ні про яку виразну ідеологічну складову махновщини, в основі якої були неписьменні бідняцькі верстви, у дослідженнях С. Сєманова мови не ведеться. Сам Батько Махно зображений автором досить критично: як переконаний анархіст, який сповідував космополітизм, тому «без сумніву, що ні українського, ні, тим паче, загальноросійського патріотизму він не знав» ${ }^{51}$.

Щодо соціальної бази махновщини, то як вважає С. Сєманов, гуляйпільський «Батько», став символом потужного народного руху не лише на теренах України, а й Півдня Росії. Історик солідаризувався з оцінкою високопоставленого більшовика Я. Яковлєва, висловленою на Всеукраїнській партконференції (1920 рік): «У махновському русі важко відрізнити, де починається бідняк, де кінчається куркуль. Це був масовий селянський рух» ${ }^{52}$. Відтак, С. Сєманов відзначав, що у районах, контрольованих РПАУ(м), трудівники користувалися дієвим соціальним захистом: у них не відбирали хліб прийшлі продзагони, їх не мобілізували до Червоної армії чи Білої гвардії. Увійшов у махновську практику розподіл конфіскованого майна і грошей: показові роздачі міській бідноті грошей, матеріальних цінностей, харчів, як наприклад, у захопленому повстанцями Катеринославі ${ }^{53}$.

На думку Ю. Латова, проголосивши вимоги народного самоврядування та вільного господарювання, махновці дотримувалися їх у своїй економічній політиці ${ }^{54}$. За Латовим, причиною популярності економічних гасел махновців серед трудящого люду була гнучкість їх соціально-економічної політики, яка опиралася на потреби місцевого люду, відбиті у колегіальних рішеннях. Анархісти Махна змирилися із стихійним ринковим товарообміном, мішечництвом, тимчасово заміщуючи ним свою програмну ідею прямого товарообміну між селом і містом - «товариського продуктообміну» ${ }^{55}$.

С. Волк доводить, що із заміною безконтрольної продрозкладки нормованим продовольчим податком (1921 р.) настрої у лавах повстанців змінилися на користь мирного господарювання ${ }^{56}$. Втішені такою можливістю та проголошеною більшовиками амністією, махновські середняки та бідняки поверталися до власних домівок. Тому, як наголосив С. Вовк, в умовах справжньої облави, влаштованої радянськими частинами на махновців ще 3 кінця 1920 р., і їх вимушеного відриву від базових територій, відтепер до них приєднувалися тільки ті, хто не попадав під амністію, та куркульські елементи, які мали найбільше підстав ненавидіти владу експропріаторів. Як спостерегли російські дослідники, 3 відміною продрозкладки (березень 1921 р.) відбувався масовий відтік селянства з махновської армії.

Як на нас, ближчими до адекватного пояснення еволюції соціальної бази махновщини є історики, які звірили свої висновки з документами учасників подій з різних воюючих сторін. Зокрема, О. Бєлаш, у додатках до спогадів свого батька, навів доповідну записку більшовицького заступника голови Революційного військового трибуналу Північної залізниці А. Аладжінова за вересень 1920 р., де засвідчено, що Нестор Махно вже третій

\footnotetext{
${ }^{51}$ Семанов С.Н. Под черным знаменем... С. 19.

${ }^{52}$ Цит. за: Семанов С.Н. Под черным знаменем... С. 44.

${ }^{53}$ Семанов С.Н. Под черным знаменем... С. 46.

${ }^{54}$ Латов Ю.В. Теневая экономика времён гражданской войны - общее и особенное // Теневая экономика: экономический и социальный аспекты: пробл.-тематич. сб. Москва, 1999. С. 92-102.

${ }^{55}$ Ibid. C. 97.

${ }^{56}$ Волк С.С. Нестор Махно...
} 
рік хазяйнує у Катеринославській губернії, живлячись зазвичай коштом реквізицій майна поміщиків і куркулів. А. Аладжінов визнав, що формування РПАУ постійно поповнювалися саме завдяки селянській і робітничій бідноті, яка таким способом здобувала шанс позбавитися злиднів і голоду ${ }^{57}$.

Таким чином, виступ селян на чолі з Н. Махном визнається російськими істориками як такий, що мав, найперше, соціально економічні цілі: виборні ради як органи регуляції життєвого укладу; вільне селянське землеволодіння; вільний ринок і т. ін. Щодо національного наповнення, то воно знайшло відображення, по-перше, у соціальній базі повстанців; по-друге, в їхній прихильності до українських козацьких традицій; по-третє, у тому, що соціально-економічна програма повстанців відбивала особливості української ментальності, пов'язані з вільним господарюванням на власній землі. Отже, як вважається в Росії, український національний аспект махновського руху виявився майже цілковито поглинутим явищами іншого - соціального порядку, мав соціалізовану форму вияву у вигляді вільної трудової громади.

Дійсно, сам «батько» запізно зацікавився українським питанням і не схвалював політику Директорії, оскільки за його міркуваннями як анархіста, петлюрівці, як державники, відстоювали інтереси національної буржуазії та поміщиків. «Він не міг підтримувати ï ідею про незалежну Українську державу і тому, що був анархістом-антидержавникам, супротивником будь-якої державної влади ${ }^{58}$ - зауважили Т. Шанін, В. Кондрашин і Н. Тархова. Так само С. Сєманов, який, з шовіністичних позицій, приписав петлюрівцям антисемітизм і русофобію, відзначав, що Н. Махно, як послідовний прибічник безвладдя, не міг стати на бік ні національної державності, ні більшовицької диктатури пролетаріату $^{59}$. Менше 3 тим, важко погодитися 3 висновком С. Волка, який вважає, що «ідея проголошення самостійності України для Н.I. Махна була неприйнятною... Вона не стала популярною на лівому березі Дніпра, оскільки там проживало різне за етнічним складом населення: українці, росіяни, греки, євреї» ${ }^{60}$.

Насправді, у програмній «Декларації» махновців, укладеній Н. Махном, В. Воліним і П. Аршиновим і прийнятій у 1919 р. на з'їзді трудящих і повстанців Півдня України стверджувалося, що метою революції є звільнення України «від усіх насильників і володарів» та здобуття незалежності України, але не національної, а в сенсі самовизначення трудящих ${ }^{61}$. Як слушно зауважив В. Савченко, автори «Декларації», помістивши підрозділ «Зносини 3 іноземними державами», навіть відійшли від головної анархістської ідеї - всесвітньої республіки Рад без всіляких кордонів і визначили Україну як субєєкт міжнародного права» ${ }^{62}$. Добавимо, що у попередньому розділі цього документу, під назвою «Захист спільного життя», махновці також неоднозначно заявили про державність України: «Усередині країни (курсив наш. - Авт.) ця армія повинна знаходитися в розпорядженні трудових робітничо-

\footnotetext{
${ }^{57}$ Белаш А.В., Белаш В.Ф. Дороги Нестора Махно. Киев: Проза, 1993. С. 437, 438.

${ }^{58}$ Шанин Т., Кондрашин В., Тархова Н. Введение... С. 18.

${ }^{59}$ Семанов С.Н. Под черным знаменем... С. 18-19.

${ }^{60}$ Волк С.С. Нестор Махно... С. 8.

${ }^{61}$ Проект декларации революционной повстанческой армии Украины (Махновиев). (Принят ВоенноРеволюционным Советом армии на заседании 20-го октября 1919 года) // Н.И. Махно. Воспоминания. Материалы и документы / Сост. В.Ф. Верстюк. Киев, 1991. С. 156-163.

${ }^{62}$ Савченко В.А. Українська складова махновського руху // Інтелігенція і влада. 2011. Вип. 21. С. 58-59.
} 
селянських організацій, захищаючи їх від будь-яких спроб насильства з боку влади і капіталу...» ${ }^{63}$. Подібні документи і практичні кроки махновців до зближення з самостійницькими силами були не випадкові і не поодинокі. Понад те, як спостеріг В. Савченко, самі анархісти 3 «Набату» у махновському керівництві документально визнавали Україну як окремний етно-територіальний простір із власною історією й особливим майбутнім і ставилися до неї як до автономної, незалежної частини колишньої Російської імперії ${ }^{64}$.

Щодо етнічного складу, то дійсно, населення Лівобережжя було більш поліетнічним і з вищим прошарком робітників, але це не означає, що українці були в меншості і що ця людність бажала жити в імперській чи більшовицькій Росії. Абсолютну більшість повстанців під орудою Н. Махна становили таки етнічні українці, вихідці із навколишніх сіл. За даними С. Рудницького, на Катеринославщині та Херсонщині, які були опорною базою махновської армії, українці становили відповідно 69 і 53\% всього населення ${ }^{65}$. А якщо брати до уваги лише сільську людність, то ці показники будуть значно вищими. Росіяни, частка яких сягала на так званій махновській території 18\%, а в повстанських лавах ще менше, фізично не могли деукраїнізувати махновську армію.

Крім окреслених вище теоретичних питань, у Росії досліджується побут повстанців (В. Єрмаков, С. Сєманов), сімейні стосунки Н. Махна (С. Сєманов), його стосунки в еміграційних колах (О. Шубін), відносини «батька» 3 його оточенням у керівництві руху та впливи на Нестора Махна окремих осіб (В. Голованов, С. Сєманов, В. Теліцин), механізми еволюції бунтарських настроїв у середовищі селянства на історичному тлі та соціальнопсихологічний образ бунтаря - рядового і керівника (В. Голованов, В. Теліцин) тощо. Але найбільшої уваги надається життєпису Нестора Махна у контексті збройної боротьби повстанців з більшовиками та білогвардійцями.

Висновки. Підсумовуючи стан сучасної російської історіографії махновщини, відзначимо, що на зміст робіт з історії громадянської війни та махновського руху кардинально вплинув розпад Радянського Союзу. Дослідники Російської Федерації позбавилися комуністичної цензури, одержали доступ до архівних документів з історії махновщини й отримали можливість використати весь методологічний арсенал, щоб, нарешті, адекватно відобразити роль і місце махновського руху в історії. У результаті за останнє 30-ліття у російській історіографії досягнуто теоретичного прориву у відображенні героїчних і трагічних сторінок повстанської боротьби під орудою Н. Махна, оцінки її причин, обставин і значення.

В останні роки у Російській Федерації тема махновського руху набула «нового дихання», що засвідчили не лише статті, а дисертації та монографії з цієї теми, численні популярні видання. У потоці російської наукової літератури спостерігаються три основні методологічні підходи: 1) автори, які, як правило, розглядають махновське повстанство крізь призму селянської війни 1917-1922 рр., не переймаючись його ідеологічними вподобаннями; 2) дослідники, які досліджують історію анархізму і, зазвичай, наголошують на анархічному характері махновщини та поглядах його очільника; 3) науковці, які заперечують анархічний характер махновського руху і наполягають на його стихійному харак-

\footnotetext{
${ }^{63}$ Проект декларации... С. 162.

${ }^{64}$ Савченко В. «Єдиний анархізм» конфедерації «Набат» // Всеукраїнська наук.-метод. конференція «Україна: становлення незалежності» / ОДУ ім. І.І. Мечникова. Одеса, 1993. Ч. 1. С. 52.

${ }^{65}$ Рудницький С. Чому ми хочемо самостійної України. Львів: Світ, 1994. С. 264-265.
} 
тері, представляючи цей рух як народний бунт. Особливістю російської історіографії є зміщення фокусу наукових студій з традиційних питань про причини і обставини махновського руху, його соціальну базу та військові звитяги на ідеологічні орієнтири повстанців, перипетії махновського повсякдення, соціально-психологічні мотиви діяльності Н. Махна і його сподвижників, на засадах просопографії, антропологічної, культурологічної, соціально-психологічної методології.

Водночас, на тлі розлогих літературних інтерпретацій, на наш погляд, мало уваги надається контент-аналізу праць самого Нестора Махна, особливо раннього періоду, які, зважаючи на відвертість автора, служать цікавим та інформаційним джерелом для розуміння мотивів і вчинків селянського «батька», його взаємовідносин з близьким оточенням і ставлення до різних військових і політичних формацій.

До недоліків російської історіографії можна віднести також на недооцінку української історіографії махновського руху, зокрема, досліджень Д. Архірейського, В. Савченка, Г. Турченко, В. Чопа й ін. Зокрема, не набула належної уваги цікава думка В. Чопа, висловлена ще 2002 р.: «Махновська ідеологія підійшла до вироблення власного варіанту української ідеї. ...Однак, проекція махновського руху на національне життя дає підстави говорити про нього як про окрему форму національного руху, що сповідував інший принцип організації суспільства» ${ }^{66}$. Цю ідею розгорнув і конкретизував В. Савченко: «Під час громадянської війни на Півдні України формувалася своєрідна місцева форма анархізму «український мілітарний (отаманський) анархізм», що об'єднував ідеї класичного анархізму, козацькі демократичні отаманські державотворчі традиції, ідеї автономізму, лібертізму та лібералізму» ${ }^{67}$. Так само актуальними для подальшого дискурсу залишається міркування Г. Турченко у контексті політичного дрейфу Н. Махна до спілки з українськими державницькими силами у 1920-1921 рр.: «Разом 3 тим, політична еволюція Н. Махна і очолюваного ним руху - від неприйняття української національної ідеї до готовності діяти узгоджено з її прихильниками, засвідчила про здатність націотворчого начала підпорядковувати своїм історичним завданням ще одну течію принципових противників самостійності України - анархо-комуністів» ${ }^{68}$.

Проте предметна дискусія науковців двох країн щодо ідеологічних особливостей махновського руху, яка посприяла б прирощенню наукових знань, поки що не склалася, насамперед, через «варіння у власному соку» з обох боків. Більшість російських дослідників недооцінюють значення запорізьких традицій та української ментальності у військовій і виробничій організації махновців, наміри Н. Махна продовжити боротьбу разом із самостійницькими силами, у тому числі на теренах Галичини і боротися за незалежність України. Тому українським науковцям, очевидно, доведеться і надалі спростовувати великодержавні спроби віднести махновщину до явища російської революції. «Як це так: українець Махно, і раптом - дзеркало Російської революції? Але в тому й річ, що ні сам Махно, який розмовляв російською, і сама Російська революція 1917-1922 рр., не визнава-

\footnotetext{
${ }^{66}$ Чоп В.М. Махновський рух в Україні 1918-1921 роки: проблеми ідеології, суспільного та військового устрою: автореф. дис... канд. іст. наук: 07.00.01. Запоріжжя, 2002. С. 11-12.

${ }^{67}$ Савченко В.А. Українська складова... С. 56.

${ }^{68}$ Турченко Г.Ф. Махновський рух і українська ідея // Наукові праці історичного факультету Запорізького національного університету. 2017. Вип. 48. С. 96.
} 
ли кордонів, що утворилися на теренах зниклої імперії. Вони діяли зі світовим прицілом, i вже у всякому разі не в межах нових держав. ...Та й сам район, де розгорнулося Махновський рух, тоді можна було віднести до України умовно» ${ }^{69}$, - розмірковує О. Шубін, всупереч фактам про національний складник руху.

Загалом стан дослідження російськими науковцями махновського повстанського руху ще не задовольняє запити сучасної історичної науки. У більшості праць аналітичносинтезний і всебічний підходи заміщуються телеологічним прийомом 3 ілюстративним описом подій і явищ. Тому об’єктивно визріли потреби подальших аналітичних студій теорії та практики махновської боротьби і створення спеціальних узагальнюючих праць, які б збагатили історіографію селянського повстанського руху доби Української революції і визвольних змагань 1917-1921 pp.

\title{
Victor Hudz, Maxym Kovalyov
}

\section{Current State of Research in the Ideology of the Makhnovist Movement in Russian Historiography}

\begin{abstract}
The article notes that public and scientific interest in the anarchist model of social reorganization, tested by the peasant movement under the leadership of N. Makhno has been an increase in the Russian Federation in the last 30 years. The features of modern Russian researchers' coverage of the main theoretical questions of the history of the Makhnovshchyna are revealed. These problematic issues include the nature, causes and consequences of the Makhnovist uprising; changes in the social base of the Makhnovshchyna; the degree of influence of anarchist ideology on Makhno and the Makhnovists, the development of anarchist theory by the «father» and his associates; degree of Ukrainian self-identification N. Makhno; socio-economic motives of the Makhnovist movement; the place and significance of the Makhnovist movement in the history of peasant movements; the phenomenon of N. Makhno's personality as a revolutionary and a peasant leader, and things.

Three main methodological approaches are observed in the stream of modern scientific literature in Russia: 1) authors who consider the Makhnovist insurrection through the prism of the peasant war, without caring about its ideological preferences; 2) researchers who insist on the anarchic nature of the Makhnovshchina and the views of its leader; 3) scientists who deny the anarchic nature of the Makhnovist movement and insist on its spontaneous nature, presenting this movement as a popular revolt. A peculiarity of Russian historiography is the shift in the focus of scientific research from traditional questions about the causes and circumstances of the Makhnovist movement, its social base and military campaigns on the ideological orientations of the rebels, the vicissitudes of the Makhnovist everyday life, the sociopsychological motives of the activities of N. Makhno and his associates on the basis of prosopography, anthropological, cultural, socio-psychological methodology. At the same time, against the background of extensive literary interpretations, in our opinion, little attention is
\end{abstract}

\footnotetext{
${ }^{69}$ Турченко Г.Ф. Махновський рух і українська ідея... С. 96; Шубин А.В. Анархия - мать порядка. Москва: Эксмо «Яуза», 2005. https://royallib.com/read/shubin_aleksandr/anarhiya_mat_poryadka.html\#20480
} 
paid to the content analysis of the works of Nestor Makhno himself, especially of the early period, which, given the author's frankness, serve as an interesting and informational source for understanding the motives and actions of the peasant «father», his relationship with his close circle and attitude to various political formations.

The disadvantages of Russian historiography can also be attributed to the underestimation of the Ukrainian historiography of the Makhnovist movement, in particular, the studies of D. Arkhireyskiy, V. Savchenko, V. Chop and others, which, despite a similar gap in Ukrainian studies, means the absence of a substantive discussion of scientists from the two countries on this topic, which would contribute to the growth of scientific knowledge. On the whole, the state of research by Russian scientists of the Makhnovist insurrectionary movement does not yet satisfy the needs of modern historical science. Objectively, the need for further research on the theory and practice of the Makhnovist struggle and the creation of special works that would enrich the historiography of the peasant insurrectionary movement of the revolutionary period of 1917-1921 has matured.

Keywords: modern Russian historiography, thematic directions, methodology, Makhnovist movement, peasant uprising, anarchism 